\title{
Massive Fire Incidents of Multiple Aboveground Storage Tanks due to Vapor Cloud Explosion
}

\author{
Shoichi Yoshida ${ }^{\mathrm{a}, *}$ \\ ${ }^{a}$ Institute of Advanced Sciences, Yokohama National University, Yokohama, Japan. Email:yoshida-shoichi-pg@ ynu.ac.jp
}

\begin{abstract}
The vapor cloud explosion (VCE) begins with a release of a large quantity of flammable vaporing liquid from a storage tank, transportation vessel or pipeline. If VCE occurs in an oil storage facility, multiple tanks burn simultaneously. There is no effective firefighting method for multiple tanks fire. It will be extinguished when oil burned out spending several days. Many incidents of multiple tanks fire due to VCE have occurred all over the world in recent 50 years. This paper reviews the past 6 incidents of multiple tanks fire due to VCE.
\end{abstract}

Keywords: Aboveground storage tank; incident; multiple tanks fire; overfill; vapor cloud explosion

\section{Introduction}

The VCE begins with a release of a large quantity of flammable vaporing liquid from a storage tank, transportation vessel or pipeline. After vapor diffuses like clouds in the atmosphere, it ignites explosively. If VCE occurs in an oil storage facility, multiple tanks burn simultaneously. Today there is no effective firefighting method for multiple tanks fire. It will be extinguished when oil burns out after several days. In addition, the fire causes severe environmental problem.

During the last half century, many VCEs have occurred in oil storage facilities. This paper reviews the VCEs at oil storage facilities that occurred in United States in 1975 and 1983, Italy in 1985, United Kingdom in 2005, and Puerto Rico and India in 2009.

\section{Gulf Oil refinery in Philadelphia [1]}

On August 17, 1975, at 5:57 am, VCE occurred in a refinery of Gulf Oil Corporation at Girard Point in Philadelphia, Pennsylvania, USA. One crude oil storage tank and two naphtha storage tanks exploded, causing massive fire, and extinguishing 10 days later. In this incident, 8 firefighters died and 14 were injured. This refinery was built

${ }^{*}$ Corresponding author. Tel.: +81-45-339-4458

79-5, Tokiwadai, Hodogaya-ku

Yokohama, Japan, 241-8501 in 1905 and had a crude oil refining capacity of 180,000 barrel per day. As shown in Fig.1, the refinery is near the Philadelphia International Airport with the Schuylkill River at the confluence of the Delaware River.

At 0:45 am on the incident day, No.231 internal floating roof tank with nominal capacity $11,900 \mathrm{~m}^{3}$ received crude oil from the tanker "Afran Neptune" by a pipeline. The tank was jointed by rivets, built in 1929. Even when the maximum liquid level was exceeded, the tank continued to receive crude oil, the oil leaked onto the floating roof and the hydrocarbon vapor began to leak from the vents on the fixed roof.

The boiler room next to the west side of the tank became the ignition source, and a small explosion occurred outside the tank at 5:57 am. The explosion caused crude oil leakage from the tank's vent. In addition, a fire broke out in a small sized No.114 fuel storage tank located in the same dike area. The fire contained at 8:44 am, 8 hours later.

The drains inside the refinery did not function, and the fire extinguishing agent used for firefighting activities and water for fire extinguishing were mixed with leaked crude oil and naphtha and collected like a pool on the east side of the No. 231 tank. An explosion and fire occurred again at this location at 4:41 pm, and many firefighters were killed and injured. This fire also burned No. 239 and No. 240 naphtha storage tanks and extinguished on August 26. 


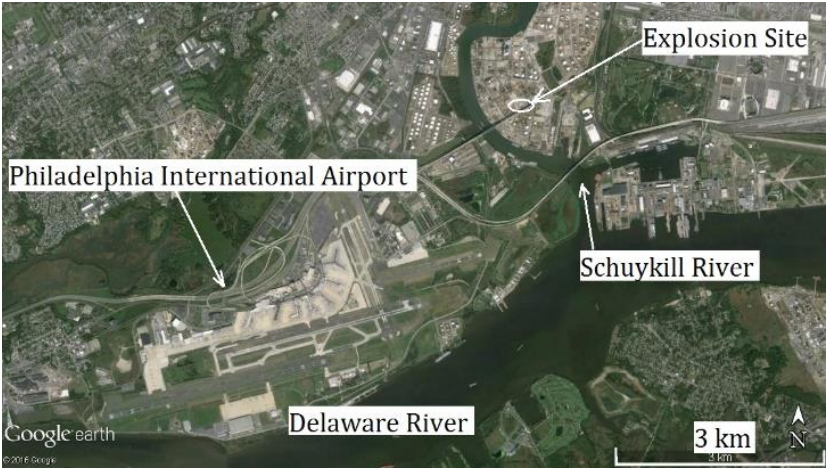

Figure 1. Philadelphia, Pennsylvania, USA (from Google Earth)

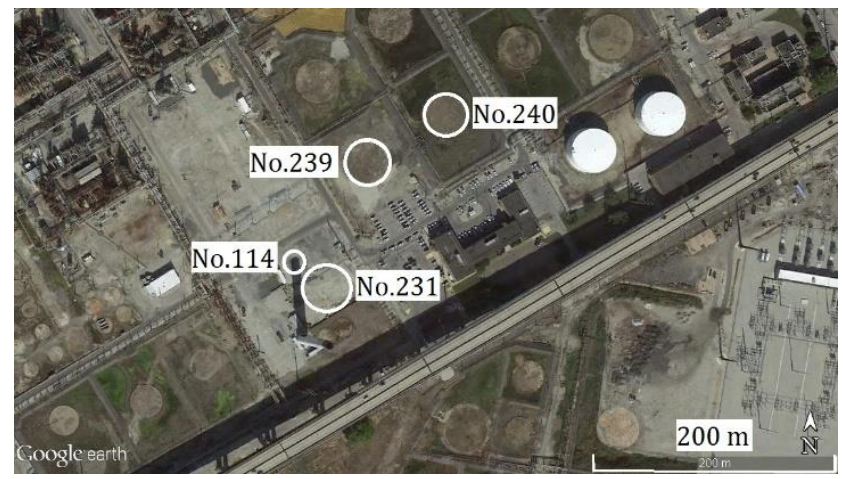

Figure 2. Former Gulf Oil refinery in Philadelphia taken on October 8, 2011 (from Google Earth)

Figure 2 is a Google earth photo taken on October 8, 2011. The burned tank had already been removed, but the tank foundation remained. The cause of this incident is that the No. 231 tank overflowed while receiving crude oil, and the leaked hydrocarbon vapor ignited at the boiler room. In 1985, Gulf Oil Corporation merged with Standard Oil of California Co. to become Chevron Corporation. A massive fire broke out again at this refinery on June 21, 2019. The refinery was owned by Philadelphia Energy Solutions Inc. at the recent incident.

\section{Texaco tank terminal in Newark [2]}

On January 7, 1983, at 0:25 am, there were three largesized gasoline storage tank fires due to VCE at the Texaco tank terminal in Newark, New Jersey, USA. The impact of the explosion was felt even in metropolitan areas such as Manhattan, Queens, Brooklyn in New York City. As shown in Fig.3, the site is several kilometers east of Newark Liberty International Airport. Figure 4 is a Google earth photo of the site taken in July 2007. The tank had already been removed, but the foundation remained. TK65, TK66, and TK67 were gasoline storage tanks where a fire broke out at the terminal.

Table 1 shows the size of the three gasoline storage tanks. The distance between each tank was 15 feet $(4.6 \mathrm{~m})$ to 30 feet $(9.1 \mathrm{~m})$. A small-seized TK66 was also in the same area.
The terminal supplied fuel to gas stations in northern New Jersey.

From January 6, 1983, the day before the incident, the TK67 tank had received gasoline from the pipeline. According to the company's operation manual, liquid level measurement was to be performed sequentially during acceptance to understand the liquid volume inside the tank, but this was not done on this day. Therefore, the liquid level reached the tank height and the gasoline overflowed. The worker noticed it at 11:50 pm, and a lot of gasoline had already leaked and vapor cloud had been generated. The tank was not equipped with a high level alarm or overfill prevention system.

The point marked "Ignition Site" in Fig.4 is a steel drum repair plant of Central Steel Drum Company, which is about $300 \mathrm{~m}$ away from TK67. An incinerator was ignited at this plant, and VCE occurred at 0:25 am on January 7. At the time of the explosion, the wind speed was $5 \mathrm{~m} / \mathrm{s}$ from the southeast. In Fig.4, the incinerator was on the leeward side of TK67, and it was easy for vapor cloud to flow.

The three tanks continued to burn for three days and were extinguished when the gasoline was burned out. The burned gasoline is 3 million gallon $\left(11,400 \mathrm{~m}^{3}\right)$. The incident killed a 40 -year-old Texaco truck driver and injured 24 people. In addition, 45 freight cars were damaged in the freight train yard of Oak Island Conrail, which is adjacent to the southwest side of the site at the lower left of Fig. 4.

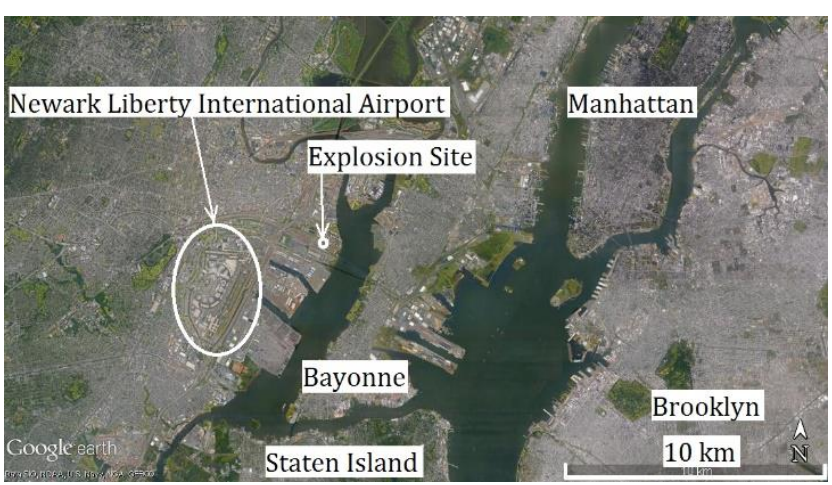

Figure 3. Newark, New Jersey, USA (from Google Earth)

Table 1. Tank list of Texaco tank terminal in Newark

\begin{tabular}{cccc}
\hline $\begin{array}{l}\text { Tank } \\
\text { No. }\end{array}$ & Diameter & Height & $\begin{array}{c}\text { Nominal capacity } \\
\text { (Estimated) }\end{array}$ \\
\hline TK64 & $57.0 \mathrm{~m}$ & $17.1 \mathrm{~m}$ & $41,000 \mathrm{~m}^{3}$ \\
TK65 & $36.6 \mathrm{~m}$ & $17.1 \mathrm{~m}$ & $16,800 \mathrm{~m}^{3}$ \\
TK67 & $24.4 \mathrm{~m}$ & $14.6 \mathrm{~m}$ & $6,300 \mathrm{~m}^{3}$ \\
\hline
\end{tabular}




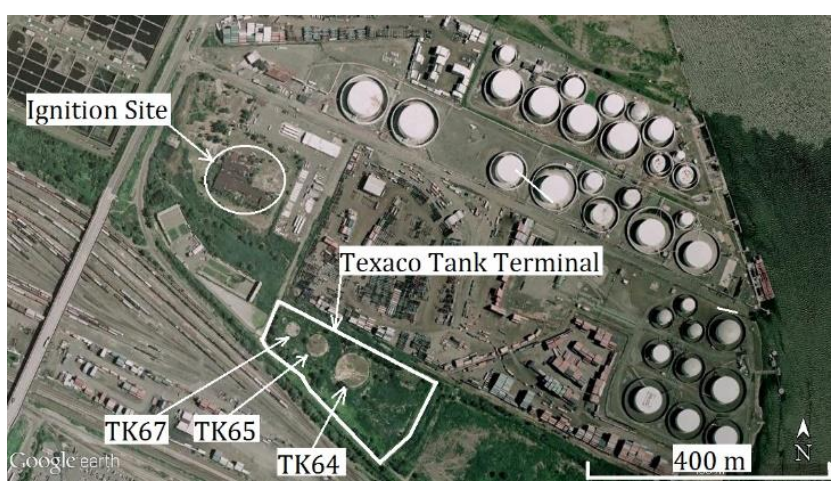

Figure 4. Former Texas tank terminal in Newark taken in July, 2007 (from Google Earth)

Texaco merged with Chevron in February 2001 to become Chevron Texaco, and changed its name to Chevron Corporation in May 2005. There are several dozen tanks on the north side of the Texaco terminal at the top of Fig.4. These tanks were also present at the time of the 1983 incident. The owner at that time is unknown.

\section{AGIP tank terminal in Naples [3]}

On December 21, 1985, at 5:13 am, 24 oil storage tanks out of 37 tanks fired due to VCE at the Italian oil company AGIP's tank terminal in the San Giovanni a Teduccio district of Naples, Italy, and burned for 6 days.

On the afternoon of the day before the incident, the tankers "Agip-Gala" started to transfer gasoline to No. 17 and No. 18 tanks in the terminal. It was not normal for this tank terminal to accept multiple tanks at the same time, but the reason is unknown. Both tanks were scheduled to reach full capacity on December 21, at 6:30 am. However, the valve of the No.18 tank inlet line was closed, and as a result, the No.17 tank received all gasoline. No. 17 tank became full sooner than planned, and overflowed at 3:20 am on the 21st. The leaked gasoline remained inside the dike area, and vapor cloud was generated.

By 5:13 am, two hours after overflow occurred in the No. 17 tank, about 700 ton of gasoline leaked and VCE occurred. The ignition source is the nearby pump room. 24 tanks burned, and the fixed roof of 6 tanks flew about $50 \mathrm{~m}$. The fire extinguished on December 27, seven days later. The incident killed 5 people, injured 170, and evacuated more than 2,000 nearby residents.

At the tank terminal, fuel such as gasoline and diesel was stored in 37 tanks up to $100,000 \mathrm{~m}^{3}$. The temperature at the time of the explosion was $8^{\circ} \mathrm{C}$ and the wind speed was $2 \mathrm{~m} / \mathrm{s}$. AGIP was merged with Eni Corporation in 2003.

\section{Buncefield tank terminal in Hemel Hempstead}

At 6:01 am on December 11, 2005, VCE occurred in Buncefield Hertfordshire Oil Storage Depot (Buncefield tank terminal) in Hemel Hempstead, $35 \mathrm{~km}$ northwest of
London, UK. The fire that burned 23 oil storage tanks lasted for five days. Forty-three people were injured and about 2,000 residents were temporarily evacuated in this incident, but fortunately there were no victims. The incident investigation committee jointly established with the UK Health and Safety Executive and the Environmental Agency issued a final report [4] in December 2008. Figure 5 is a Google earth photo of the Buncefield tank terminal taken on December 31, 2000 before the incident.

The Buncefield tank terminal was built in 1968 and was an oil storage facility jointly operated by three companies. Three pipelines received petroleum products from domestic refineries and ports, supplied them by tanker trucks to London and southeast England, and also supplied aviation fuel to Heathrow International Airport by pipelines.

The TK912 internal floating roof tank began accepting unleaded gasoline from a pipeline at $7 \mathrm{pm}$ on December 10, the day before the incident. The liquid level of the tank was controlled in the control room by the Automatic Tank Gauging System, but the indication of the liquid level gauge stopped working around 3 am the next day. Filling continued, the liquid level reached the tank height around 5:30 am, overflowed from the top of the tank, and a vapor cloud was generated. The explosion occurred at 6:01 am and the ignition source is unknown.

This VCE burned 23 oil tanks. The massive fire contained on the afternoon of 12th, 32 hours later, but the small fire continued on the 13th. On the 14th, a new fire broke out in one oil storage tank, and the fire extinguished on the 15th. Due to this fire, $750 \mathrm{~m}^{3}$ foam extinguishing agent and 55,000 $\mathrm{m}^{3}$ fire extinguishing water were used. The amount of gasoline leakage until the explosion is 300 ton.

Figure 6 is an aerial photo of this fire, and Figure 7 is a Google earth photo taken on December 31, 2006, one year after the incident. It is confirmed that the burned tanks remained and did not hold the prototype.

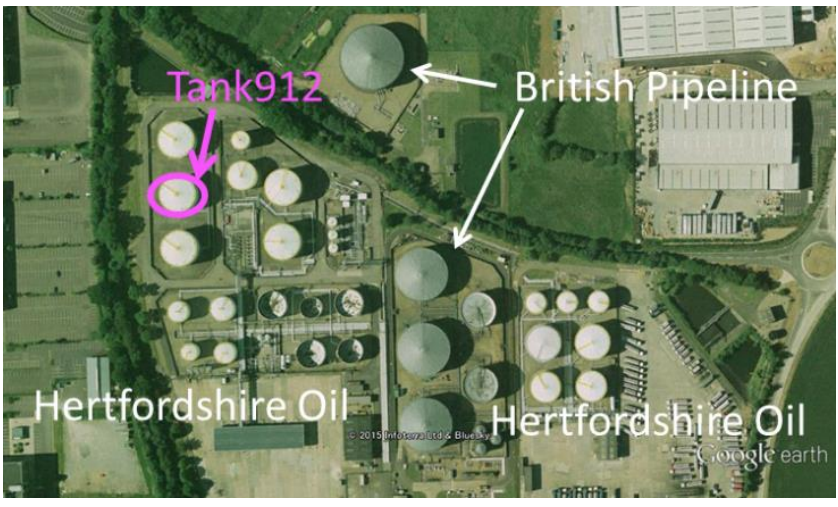

Figure 5. Buncefield tank terminal taken before the incident (from Google Earth) 


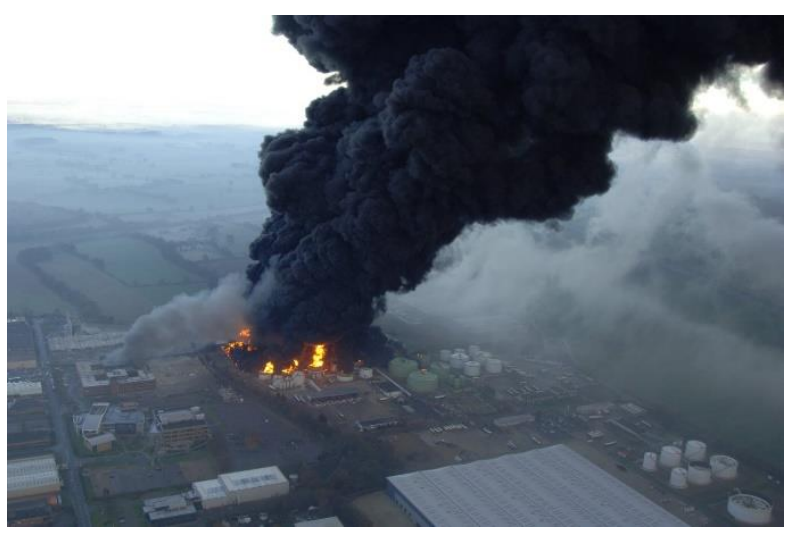

Figure 6. Massive fire in Buncefield tank terminal [4]

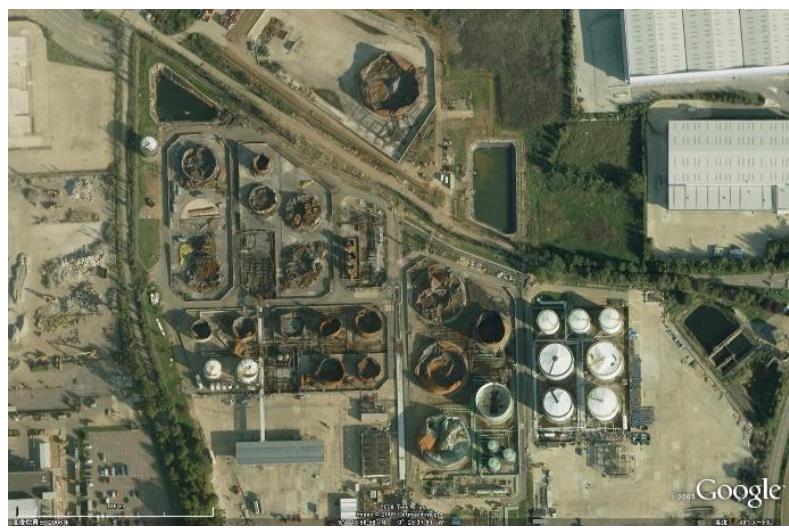

Figure 7. Buncefield tank terminal after the incident taken on December 31, 2006 (from Google Earth)

\section{CAPECO tank terminal in Puerto Rico}

\subsection{CAPECO tank terminal}

On October 23, 2009, at 0:23 am, there was a massive fire of 17 oil storage tanks due to VCE at the Caribbean Petroleum Corporation (CAPECO) tank terminal in Bayamon near the capital of San Juan, Puerto Rico. It took 59 hours to extinguish. Three nearby residents were slightly injured and hundreds of houses were damaged by the impact of the explosion, but fortunately there were no victims. The cause of the incident was investigated by the U.S. Chemical Safety and Hazard Investigation Board (CSB), and a final report[5] was issued on October 25, 2015.

Figure 8 shows the location of CAPECO in Bayamon. The company had opened as a refinery in 1955, but went bankrupt in 2001. After that, the refinery was abandoned and the operation continued as a tank terminal with 170 gas stations in the island, which continued until the day of this incident. In San Juan Bay, $4 \mathrm{~km}$ northeast of the tank terminal, there was a dock where tankers are anchored, from which oil was transferred to tanks in the terminal by pipelines. The terminal had 48 oil storage tanks that store 90 million gallons $\left(340,000 \mathrm{~m}^{3}\right)$ of gasoline, aviation fuel,

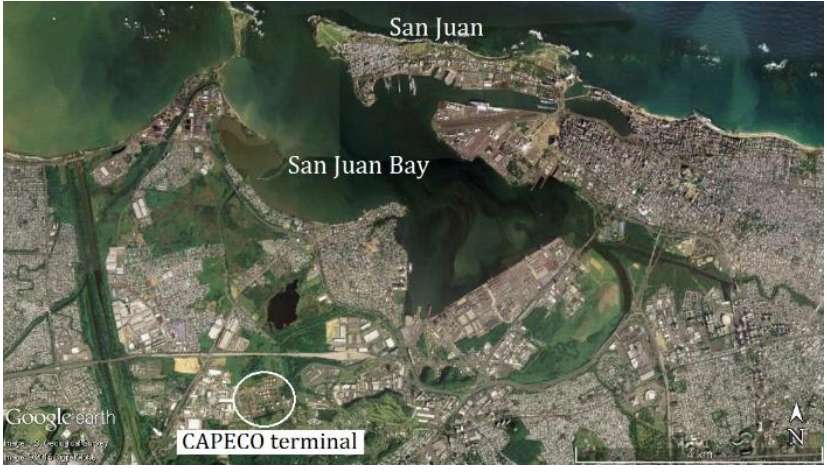

Figure 8. CAPECO location in Perto Rico (from Google Earth)

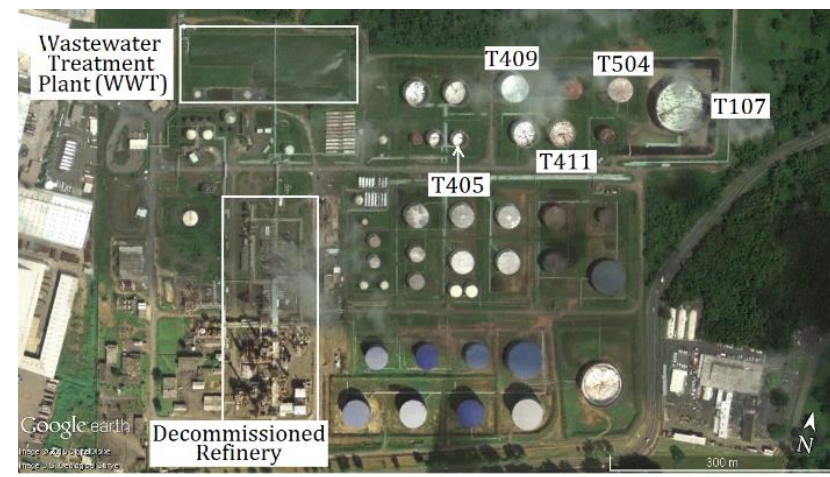

Figure 9. CAPECO tank terminal before the incident taken on November 30, 2006 (from Google Earth)

diesel, etc. Figure 9 shows this tank terminal layout before the incident.

CAPECO site consists of four areas: a tank terminal, an abandoned refinery, a wastewater treatment plant(WWT), and a management building as shown in Figure 9. WWT is a pond for storing rainwater and oil containing water, and has its treatment facility.

\subsection{Incident of CAPECO}

On October 21, 2009, a tanker loaded with 11.5 million gallon $\left(43,600 \mathrm{~m}^{3}\right)$ of unleaded gasoline and anchored at the CAPECO dock in San Juan Bay. Gasoline was decided to transfer to four tanks, that is T405, T504, T409 and T411, from the tanker by pipeline.

The transfer to T405 and T504 was completed by noon on October 22. Next, transfer of T409 and T411 was prepared. The inlet lines for both tanks were the same. The operator set the T409 valve to "full open" and the T411 to "partially open". It was sent to T409 at 7,000 gallon/min. $\left(26.5 \mathrm{~m}^{3} / \mathrm{min}\right.$.) and to T411 at a lower flow rate. Around $6: 30$ $\mathrm{pm}$, the tank operator read the liquid level of T409 from the on-site indicator of the float-type liquid level gauge, and reported it to the manager. The manager estimated the T409 full liquid time at $9 \mathrm{pm}$ on October 21. 


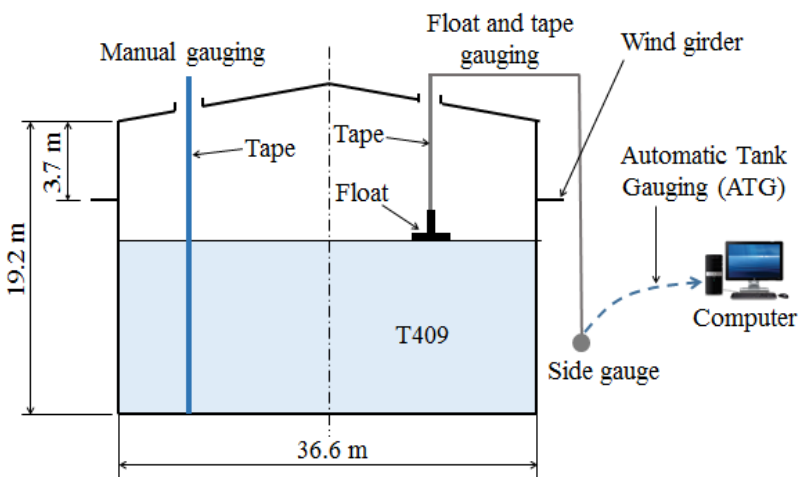

Figure 10. Tank gauging system in T409 tank

Figure 10 shows a liquid level gauging system of the T409 tank. As the transmitter of the float type liquid level gauge was in failure, the liquid level could not be controlled by computer using the automatic tank gauging. In addition, the high level alarm and the overfill prevention system, which were independent from the liquid level gauge, were not installed. As shown in Figure 10, T409 had a diameter of $36.6 \mathrm{~m}$, a height of $19.2 \mathrm{~m}$ and a nominal capacity of 19,000 $\mathrm{m}^{3}$. It was a fixed roof tank with an aluminum internal floating roof.

If the T409 tank continued to be receive gasoline, the estimated full liquid time would overlap with the work shift time. The operator set the T411 valve to "full open" and the T409 to "partially open". The scheduled full liquid time of T409 was delayed, and T411 would become full at 10:00 pm. After 10:00 pm, the valve of T409 was set to "full open", and the manager estimated full liquid time at 1 am on October 23. However, this estimation was not accurate, and gasoline overflowed from T409 between 11:00 am and midnight on the next day. It leaked from six vents on the fixed roof and flowed into the dike area while generating vapor clouds.

When the operator came near T409 to measure the liquid level at 0:00 am on October 23rd, he felt something like a white mist up to 3 feet $(0.91 \mathrm{~m})$ high from the ground and gasoline odor. Because the lighting on the site was dark, he could not see gasoline flowing down from T409 and hear the sound. The operator asked the other operator in the dog to cancel to transfer gasoline using wireless. The fog condensed on his hands. The temperature was $26^{\circ} \mathrm{C}$ and it was light wind. T409 was located on a high ground in the tank terminal, and it was a terrain where vapor clouds could easily flow downward.

At 0:23 am on October 23, the surveillance camera at the facility adjacent to CAPECO caught the vapor cloud in the WWT area suddenly shining and ignited. Seven seconds later, a big explosion equivalent to Richter scale 2.9 occurred. As a result, 17 of the 48 oil tanks fired simultaneously. CSB final report [5] could not identify the ignition source. The leak start time was at $11: 57 \mathrm{pm}$ on October 22, 26 minutes before the ignition. The fire

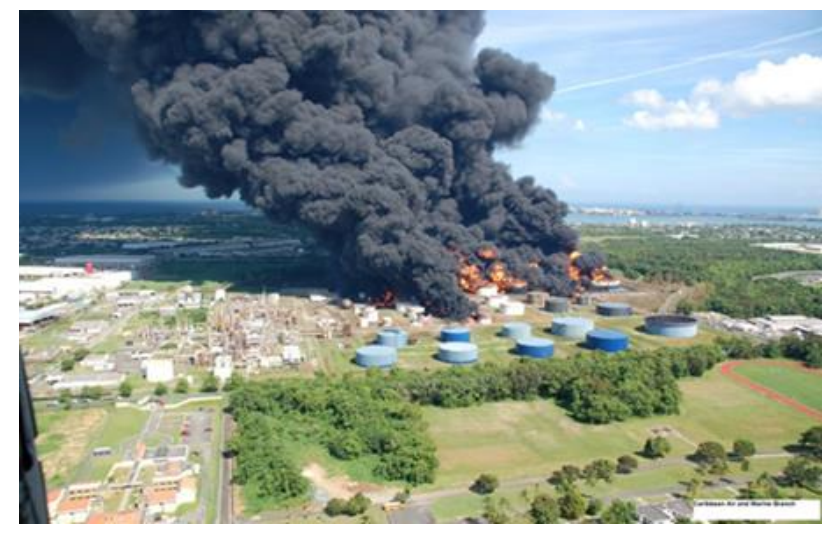

Figure 11. Massive fire in CAPECO tank terminal [5]

extinguished at 11:30 am on October 25, 59 hours later. Figure 11 is a photo of a fire in the CAPECO tank terminal [5].

CAPECO went bankrupt on August 12, 2010 due to this incident. On May 11, 2011, Puma Energy Caribe, LLC acquired the terminal and 147 gas stations in the island. In addition, the company took over the post-incident clean-up and various improvements that the regulatory authorities imposed on CAPECO.

\section{IOCL tank terminal in Jaipur}

\subsection{IOCL tank terminal}

On October 29, 2009, at 7:25 pm, massive fire of 11 oil storage tanks occurred due to VCE at the tank terminal of Indian Oil Corporation Limited (IOCL), a state owned oil company, in Jaipur, Rajasthan, India. It took 11 days to extinguish. Eleven people were killed and about 45 injured in this incident. The Ministry of Petroleum and Natural Gas constituted the investigation committee consisting of seven experts the day after the incident, and its final report[7] was submitted on January 29, 2010.

Figure 12 is a Google earth photo showing the layout of the tank terminal taken on November 14, 2011, two years after the incident. In the tank yard, which is upper middle in this figure and called "Main Tank Area", nine tanks which burned in the incident remained. These tanks stored fuel transferred from the IOCL refinery in Kojari, Gujarat. Piping Division Area was the pipeline relay station that sent crude oil to other IOCL refineries. There were two fire water storage tanks in the Fire Water \& Pumping Area.

Figure 13 shows the enlarged Main Tank Area. Table 2 shows the tank list of this terminal. There were 11 oil storage tanks, and the total nominal capacity was $110,370 \mathrm{~m}^{3}$. Nine of the eleven were located in the Main Tank Area and were grouped by three. "Motor spirit" in the table means gasoline. 


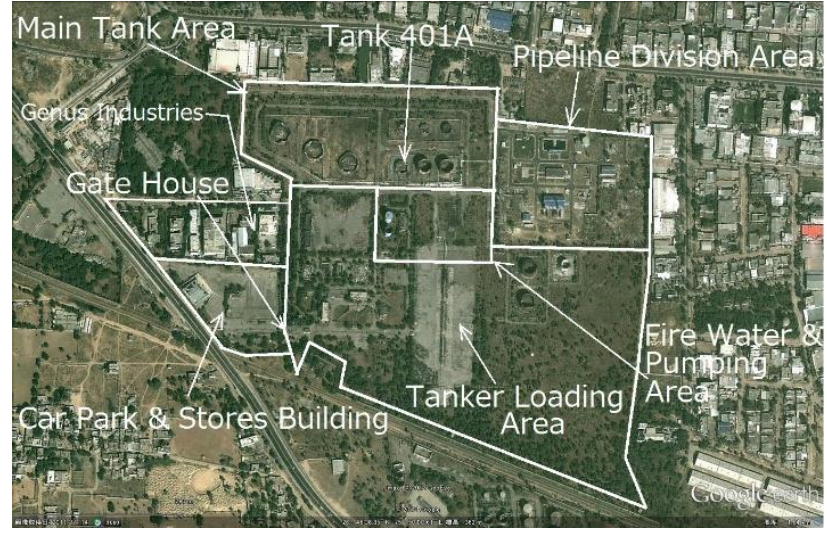

Figure 12. Layout of IOCL tank Terminal (from Google Earth)

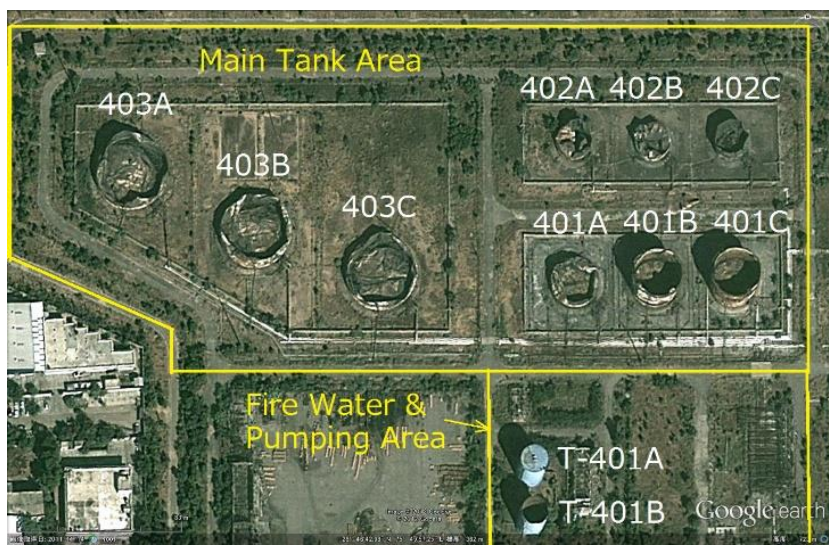

Figure 13. Main Tank Area of IOCL tank terminal (from Google Earth)

Table 2. Tank list of IOCL tank terminal

\begin{tabular}{cccccc}
\hline $\begin{array}{c}\text { Tank } \\
\text { No. }\end{array}$ & $\begin{array}{c}\text { Material } \\
\text { stored }\end{array}$ & $\begin{array}{c}\text { Nominal } \\
\text { capacity } \\
\left(\mathrm{m}^{3}\right)\end{array}$ & $\begin{array}{c}\text { Diameter } \\
(\mathrm{m})\end{array}$ & $\begin{array}{c}\text { Height } \\
(\mathrm{m})\end{array}$ & $\begin{array}{c}\text { Tank } \\
\text { type }\end{array}$ \\
\hline 401A & MS & 6,110 & 24 & 15 & FRT \\
401B & MS & 6,110 & 24 & 15 & FRT \\
401C & MS & 6,110 & 24 & 15 & FRT \\
402A & SKO & 5,080 & 18 & 20 & CRT \\
402B & SKO & 5,080 & 18 & 20 & CRT \\
402C & SKO & 5,080 & 18 & 20 & CRT \\
403A & HSD & 20,000 & 36 & 20 & CRT \\
403B & HSD & 20,000 & 36 & 20 & CRT \\
403C & HSD & 20,000 & 36 & 20 & CRT \\
409A & MS & 8,400 & 28 & 15 & FRT \\
409B & MS & 8,400 & 28 & 15 & FRT \\
T-401A & Fire Water & 2,460 & 14 & 18 & CRT \\
T-401B & Fire Water & 2,460 & 14 & 18 & CRT \\
\hline MS : Motor spirit & & FRT : Floating roof tank \\
SKO : Super kerosene oil & CRT : Cone roof tank & \\
HSD : High speed diesel & & &
\end{tabular}

\subsection{IOCL incident}

The terminal received an order for $1,567 \mathrm{~m}^{3}$ of gasoline and $850 \mathrm{~m}^{3}$ of kerosene from a customer on the morning of October 29, 2009, and was transferred by pipeline from the evening. In the Market Division, one manager and three operators were responsible for this transfer work. After starting kerosene transfer from 402A tank, they moved to 401A tank for gasoline transfer. At this time, one operator came home without permission.

At around 6:10 pm, the manager heard an operator "A" screaming on the opposite side of the 401A tank. When he rushed to there, he saw gasoline squirting from the Hammer Blind Valve vertically to the height of a human like a fountain. The operator A was soaked and had difficulty breathing. The manager took the operator A and tried to carry him to a safety place outside the dike, but the manager also became difficult to breathe due to gasoline vapor. $\mathrm{He}$ lowered the operator A, went out the dike, shouted for a gasoline leak, and then fell on the road between the 401A tank and the $403 \mathrm{C}$ tank.

Another operator "B" was drinking tea in the cafeteria at that time. He heard the sorrowful cry of the manager and rushed to the 401A tank. Furthermore, he entered the tank yard over the dike. Eventually, the operator B could not stop the leak, rescue the operator A, or return himself again. His key was found east of the 401A tank after the fire was extinguished, but nothing else was specified. The operator A's relics were also found between the 410A and 401B tanks.

Around 7:25 pm, a thick vapor cloud spread throughout the terminal, and then a major explosion occurred. The ignition source is unknown. This explosion killed 11 people and injured 45 people. Simultaneously, nine oil storage tanks in the Main Tank Area also exploded, and the fire lasted for 11 days until the fuel was burned out. The 409A and 409B gasoline storage tanks, which were away from the Main Tank Area, burned after several hours from the explosion. Figure 14 is a photo of this fire.

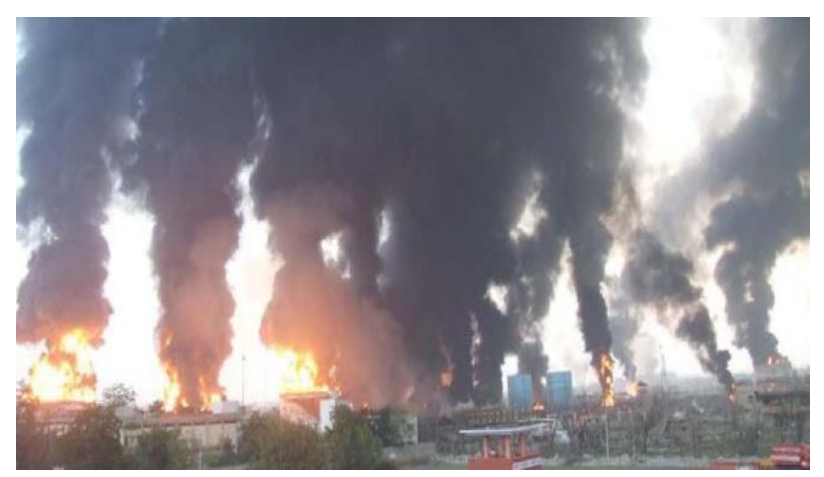

Figure 14. Massive fire in IOCL tank terminal [6] 


\subsection{Cause of IOCL incident}

In the outlet line of the IOCL tank terminal, an automatic gate valve (Motor Operated Valve: MOV), a Hammer Blind Valve, and a manual gate valve (Hand Operated Valve: HOV) were installed from the tank in order. The MOV was opened and closed remotely from the control room, but it was inconvenient to change the operation because the tanks were far from the control room. Therefore, since 2003, a panel with three buttons "open", "closed", and "stop" has been placed in front of the MOV and changed to button operation.

Hammer Blind Valve has the advantages of simple shape and easy operation, and can completely block the flow in the piping at one location. In addition, the "open" or "closed" state can be easily visually confirmed from the outside. Figure 15 shows the same type as the Hammer Blind Valve used in the 401A gasoline tank outlet line.

When the Hammer Blind Valve is "close", the solid wedge is inserted into the body of the valve. When performing the operation from "closed" to "opened" or vice versa, both wedges are pulled out temporarily and the inside of the pipeline is exposed to the atmosphere. In $10 \mathrm{inch}$ piping, the opening size is $305 \mathrm{~mm} \times 152 \mathrm{~mm}$. When changing the Hammer Blind Valve from "closed" to "open" or vice versa, the gate valves on both sides must be closed before operation. According to the photo taken after the incident of the 401A tank Hammer Blind Valve, both solid wedge and hollow wedge were outside the body, and the opening was made. In this outlet line, both the upstream MOV and the downstream HOV were "open". Therefore, gasoline was ejected from the opening of the Hammer Blind Valve.

The investigation committee [6] assumes the following valve operation errors. The operator A first opened the downstream HOV and then tried to open the Hammer Blind Valve. During this operation, there was a leak from downstream due to backflow in the opening, and the MOV "close" button should have been pressed. However, he was panicked and accidentally pressed the "open" button.

In this tank terminal, the automatic gate valve on the outlet line could be remotely operated from the control room until 2003, but at the time of the incident, only the button was operated near the valve. Leakage could be stopped if the button panel was outside the dike area or the valve could be operated remotely.

\section{Conclusions}

The simultaneous fires of multiple oil storage tanks due to VCE is extinguished when the oil is burned out after several days without effective firefighting method. VCE is also affected by weather conditions such as temperature and wind speed, and topography. In January, 2013, a gasoline tank leakage occurred in Idaho, USA. At this time, the temperature was below freezing and no vapor cloud was generated.

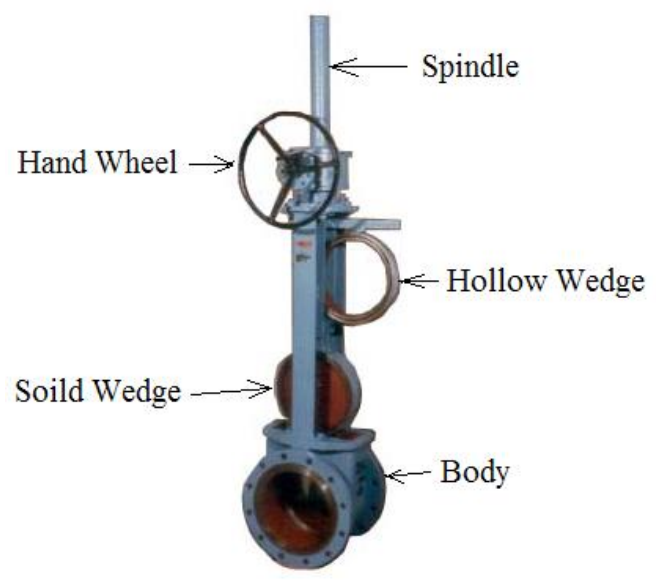

Figure 15. Hammer blind valve [6]

In the 2005 UK and 2009 Puerto Rico incidents, gasoline leaked from the fixed roof of the tank to the ground and collided with intermediate wind girders. In the 2009 India incident, gasoline erupted like a fountain. Such a diffusive situation seems to promote the generation of vapor clouds. In addition, as in the case of the 2009 India, humans have difficulty breathing in the vapor cloud.

To prevent VCE, the most important thing is not to cause a leakage, but if a leakage occurs, it must have equipment to stop it remotely. It is also important to conduct risk assessment for simultaneous fires of multiple oil storage tanks and to have training and equipment for this purpose.

\section{References}

[1] Wikipedia, 1975 Philadelphia Gulf refinery fire, https://en.wikipedia.org/wiki/1975_Philadelphia_Gulf_refinery_fire, 2019.

[2] Wikipedia, 1983 Newark explosion, https://en.wikipedia.org /wiki/1983_Newark_explosion, 2019.

[3] Maremonti, M., Russo, G., Salzano, E. and Tufano, V., Post-incident analysis of vapor cloud explosions in fuel storage areas, Trans. IChemE, Vo.77, Part B; 1999, p.360-365.

[4] Buncefield Major Incident Investigation Board, The Buncefield incident, 11 December 2005, The final report of the major incident investigation board; 2008.

[5] U.S. Chemical Safety and Hazard Investigation Board, Final investigation report, Caribbean Petroleum tank terminal explosion and multiple tanks fire; 2015.

[6] Independent Inquiry Committee, "IOC fire accident investigation report", Ministry of Petroleum \& Natural Gas, Government of India; 2010. 